\title{
EMPLOYERS' EXPECTATION OF COMPUTER TECHNOLOGY SKILLS REQUIRED OF BUSINESS EDUCATION GRADUATES FROM COLLEGES OF EDUCATION IN RIVERS STATE
}

\section{Ogolo Furo I.}

\author{
Department of Office Technology and Management Education, School of Secondary \\ Education (Business), Federal College of Education (Tech.), Omoku
}

Cite this article:

Ogolo Furo I. (2021), Employers' Expectation of Computer Technology Skills Required of Business Education Graduates from Colleges of Education in Rivers State. British Journal of Education, Learning and Development Psychology 4(2), 8-16. DOI: 10.52589/BJELDPMAHQTP5J.

\section{Manuscript History}

Received: 5 July 2021

Accepted: 12 Aug 2021

Published: 31 Aug 2021

Copyright (C) 2020 The Author(s). This is an Open Access article distributed under the terms of Creative Commons Attribution-NonCommercialNoDerivatives 4.0 International (CC BY-NC-ND 4.0), which permits anyone to share, use, reproduce and redistribute in any medium, provided the original author and source are credited.
ABSTRACT: This study examined employers' expectation of computer technology skills required of business education graduates from colleges of business education in Rivers State. To achieve the main purpose of the study, two research questions were formulated to guide the study. Descriptive survey research design was adopted to elicit responses from a sample of 100 employers of business education graduates and 200 business education graduating students drawn out of the population of 150 employers and 345 business education final year students respectively during the 2019/2020 academic session. Data collected using checklist and questionnaire were analysed using descriptive statistics of frequency count, percentage and bar chart. The findings reveal that employers of business education students in Rivers State expect the graduates to have high skills in the following computer application areas: Microsoft Word, Microsoft Excel, Desktop Publishing, Databases, Computer Networking, Website Application, POS Application, Payroll Application and Computer Internet. The findings also reveal that business education students rated their competency level in these computer application skills as low. These show that there is a gap between the expectation of the employers and the computer technology skills of business education graduates. Based on these findings, the following recommendations were put forward among others: employers of business education graduates should collaborate with the National Commission for Colleges of Education to review the curriculum content for computer application areas in business education to cover skills in areas needed for their productivity. Business education students who have already graduated and are lacking in the various computer technology skills highlighted in this study should endeavour to embark on personal development in order to develop such skills needed for employability.

KEYWORDS: Business Education, Computer Application Areas, Computer Application Skills, Employers' Expectations. 


\section{INTRODUCTION}

Business education as a programme aims at the continuous development of the human resource needs of the business world. One of its most commonly and globally accepted definitions is that which describes it as education designed to equip its recipients with knowledge, skills and attitudes for and about business (Onejota, 2012). These knowledge, skills and attitudes developed through business education are meant to make the graduates provide effective and meaningful services in the world of business as employees or employers of labour (Jegbefume, Utebor \& Kifordu, 2014). However, with the advancement in Information and Communications Technology (ICT), especially computer technology which has significantly changed the ways businesses are operated, Ezenwafor (2012) posited that business education students need to be very competent in utilizing different ICT offerings, especially computer technology software if they must meet up with the demand of the global business world.

Mehdi and Jun (2008) noted that acknowledging the need for a computer literate workforce, most institutions of learning, colleges of education inclusive have invested large components of their capital expenditure on the procurement and installation of computer and application software. In colleges of education for instance, computer laboratories are required to be provided with at least 30 sets of computer systems that are all networked to share resources for teaching and learning computer application skills in the business education programme (National Commission for Colleges of Education, NCCE, 2012). Supporting this, Ezewanfor (2012) observed that many colleges of education have put computer facilities in place for students' access. However, Caliz (2004) noted that is not just about giving students access to computer and computer training, there is a need for drastic changes in the course content and delivery system to prepare the recipients for the current demand of the labour market.

NCCE (2012) outlined the following computer application areas as requirements for graduation as a holder of Nigeria Certificate in Education (NCE) in business education:

i. Word processing using application software like Microsoft word.

ii. Data processing using application software such as Lotus/Excel (spreadsheet).

iii. Desktop publishing

iv. Decision making system, and

v. Problem solving system.

In line with the above, Chukwumezie and Ndinechi (2006) also posited that computer application areas for business education students should cover areas like word processing and spreadsheet. Omeje (2008) added that adequate knowledge and skills on internet utilization are part of the expectation for the labour market from graduates of business education. On the other hand, Ramurez (2009) outlined computer application areas like desktop publishing and PowerPoint presentation for business programmes graduates. Achilike (2007) observed that all the knowledge and skills of the various computer application areas acquired by business education students should be aimed at satisfying the demand of the labour market, while Nwanewezi and Isifeh (2008) have a contrary opinion when they noted that knowledge and skills of these applications are meant to help business education students to utilize the computer to aid their learning and personal lives. From whatever angle the relevance of the knowledge 
and skills of these computer application areas learnt by business education students is viewed, it is appropriate that they should meet the expectations of the labour market in order to make the graduates of the programme fit for labour market employment.

Mehdi and Jun (2008) noted that the curriculum of ICT or computer application courses need to be reviewed from time to time in order to reflect the needs of the labour market. These authors noted the fact that knowledge and skills of computer application areas acquired by students today are in danger of becoming obsolete rapidly because of the fast rate at which computer application software is being updated and modified. This means that a wider range of computer application skills are needed for graduates who will further the continuous integration of computer technology in doing businesses.

Several researches have been conducted on the level of exposure of business education to ICT or computer knowledge and skills needed by the present Nigeria labour market. The outcomes of the research have been mixed. For instance, Ezenwafor (2012) discovered that business education students are inadequately exposed to the utilization of various computer application software resources. Jegbefume, Utebor and Kifordu (2014) also discovered that business education students are barely proficient in word processing and spreadsheet processing application tasks required in the workplace. On the other hand, Ndinechi and Ementa (2013) discovered that students of business education rated their exposure to computer word processing skills through training very well. However, the authors also discovered that these students rated their exposure to the computer desktop publishing application as very poor through training. Oborah and Eze (2013) also discovered that office technology and management students are inadequate in terms of the keyboarding skills needed for the utilization of computer technology software used in the business world.

Furthermore, it is obvious that in this era of technology, employers of the labour force especially in the business world are not only interested in graduates with higher certificates but graduates who possess the automated skills needed for utilizing computer technology to enhance productivity. Corroborating this, Ober (2011) noted that most employment advertisements in this 21st century emphasize the need for graduates to be proficient in Microsoft Office (mostly Word and Excel). Mehdi and Jun (2008) also noted that the labour market is in search of job seekers with highly competent skills related to computer databases, networking technologies, software installation, hardware maintenance, website utilization and manipulating applications. Onou and Lucky (2014) noted that we now live in a world where company dynamics and financial state are determined with the use of computer technology such as payroll accounting software, account payable software, POS accounting software, invoice accounting software, billing accounting software, hotel accounting software, reconciliation accounting software and many more. Therefore, they recommended that accounting students need to develop the skills with which they can utilize various computer application softwares that are expected for performance in the labour market.

In the light of the above, it becomes paramount to continuously evaluate business education students' computer technology skills in line with the expectation of the labour market where they are to be engaged. This is in order to make the graduates of this programme relevant to the current labour market. It is for this reason that this study examines the computer application areas in business education and labour market expectation of business education graduates of colleges of education in Rivers State which none of the existing researches in this area has considered. 


\section{Research Questions}

The study was conducted to provide answers to the following research questions:

i. What is the competent level of computer technology skills employers of business education graduates in Rivers State expect from business education graduates?

ii. To what extent do business education graduates possess the competent level of computer application skills expected by the employers of business education graduates in Rivers State?

\section{Hypothesis}

There is no significant difference between the ICT application skills expected by employers of business education graduates and the extent of ICT application skills possessed by the graduates in Rivers State

\section{Method}

This study adopted a survey research design. The population of this study comprises 150 computer services business centres in three local government areas namely: Ahoada east, Ahoada west and Ogba/Egbema/Ndoni local government areas of Rivers State and 345 final year students of business education programme during 2019/2020 academic session from the Federal College of Education (Tech.), Omoku, Rivers State.

The study adopted purposive and simple random sampling techniques to select its sample. The purposive sampling technique was used to select 100 computer services business centres while the simple random sampling was used to select 200 final year business education students who have already been exposed to computer application areas as requirements for graduation. Therefore, the total sample comprises 100 employers of business education graduates and 200 final year business education graduates.

A checklist designed on the basis of "High Competent Level" and "Low Competent Level" of computer technology skills expected of business education graduates by employers and a questionnaire designed on three rating scales of high extent, moderate extent and low extent were used to generate data for the study. Descriptive statistics was used to analyse the data collected. The elements of the descriptive statistics used are frequency count, percentage and bar chart.

\section{RESULTS AND DISCUSSION}

Research Question 1: What competent level of computer technology skills does employers of business education graduates in Rivers State expect from business education graduates? 
Table 1: Percentage Responses of Competent Level of Computer Application Skills Expected of Business Education Graduates by Employers

\begin{tabular}{llllll}
\hline S/N & $\begin{array}{l}\text { Computer Application } \\
\text { Skills }\end{array}$ & $\begin{array}{l}\text { High } \\
\text { Competent } \\
\text { Level }\end{array}$ & $\begin{array}{l}\text { \% } \\
\text { Competent } \\
\text { level }\end{array}$ & $\begin{array}{l}\text { High } \\
\text { Cow } \\
\text { Covel }\end{array}$ & $\begin{array}{l}\text { Low } \\
\text { Competent } \\
\text { level }\end{array}$ \\
\hline 1. & $\begin{array}{l}\text { Microsoft Word } \\
\text { Application Skills }\end{array}$ & 100 & $100 \%$ & - & - \\
2. & $\begin{array}{l}\text { Microsoft Excel } \\
\text { Application Skills }\end{array}$ & 100 & $100 \%$ & - & - \\
3. & $\begin{array}{l}\text { Desktop Publishing } \\
\text { Application Skills }\end{array}$ & 100 & $100 \%$ & - & - \\
4. & $\begin{array}{l}\text { Computer Databases } \\
\text { Application Skills } \\
\text { Computer Networking }\end{array}$ & 90 & $90 \%$ & 10 & $10 \%$ \\
5. & $\begin{array}{l}\text { Application Skills } \\
\text { Website Application Skills }\end{array}$ & 80 & $100 \%$ & - & - \\
6. & $\begin{array}{l}\text { POS Accounting } \\
\text { Application Skills }\end{array}$ & 65 & $80 \%$ & 20 & $20 \%$ \\
8. & $\begin{array}{l}\text { Payroll Accounting } \\
\text { Application Skills }\end{array}$ & 70 & $70 \%$ & $35 \%$ & $30 \%$ \\
9. & $\begin{array}{l}\text { PowerPoint Application } \\
\text { Skills }\end{array}$ & 20 & $20 \%$ & 80 & $80 \%$ \\
10. & $\begin{array}{l}\text { Computer Internet } \\
\text { Application Skills }\end{array}$ & 100 & $100 \%$ & - & - \\
\hline
\end{tabular}

Source: 2015 Field Survey

Table 1 shows that the employers of business education graduates expect these graduates to have high competent level of computer application skills in the area of Microsoft Word, Microsoft Excel, Desktop Publishing, Databases, Computer Networking, Website Application, POS Application, Payroll Application and Computer Internet with percentages ranging from $65 \%$ to $100 \%$. They also do not expect business education graduates to possess a high competent level in PowerPoint Application skills (with 80\% as against 20\%).

Research Question 2: To what extent do business education graduates possess the competent level of computer technology skills expected by the employers of business education graduates in Rivers State? 
Table 2: Percentage Responses on the Extent of Competent Level in Computer Application Skills of Business Education Graduating Students

\begin{tabular}{llllllll}
\hline S/N & $\begin{array}{l}\text { Computer } \\
\text { Application Skills }\end{array}$ & $\begin{array}{l}\text { High } \\
\text { Extent }\end{array}$ & $\begin{array}{l}\text { \% High } \\
\text { Extent }\end{array}$ & $\begin{array}{l}\text { Moderate } \\
\text { Extent }\end{array}$ & $\begin{array}{l}\text { \% } \\
\text { Moderate } \\
\text { Extent }\end{array}$ & $\begin{array}{l}\text { Low } \\
\text { Extent }\end{array}$ & $\begin{array}{l}\text { \% Low } \\
\text { Extent }\end{array}$ \\
\hline 1. & $\begin{array}{l}\text { Microsoft Word } \\
\text { Application Skills }\end{array}$ & 74 & $37 \%$ & 79 & $39.5 \%$ & 47 & $23.5 \%$ \\
2. & $\begin{array}{l}\text { Microsoft Excel } \\
\text { Application Skills }\end{array}$ & 30 & $15 \%$ & 40 & $20 \%$ & 130 & $65 \%$ \\
3. & $\begin{array}{l}\text { Desktop Publishing } \\
\text { Application Skills }\end{array}$ & - & - & - & - & 200 & $100 \%$ \\
4. & $\begin{array}{l}\text { Computer Databases } \\
\text { Application Skills } \\
\text { Computer }\end{array}$ & - & - & - & - & 200 & $100 \%$ \\
5. & $\begin{array}{l}\text { Networking } \\
\text { Application Skills }\end{array}$ & - & - & - & 200 & $100 \%$ \\
6. & $\begin{array}{l}\text { Website Application } \\
\text { Skills }\end{array}$ & - & - & - & - & 200 & $100 \%$ \\
7. & $\begin{array}{l}\text { POS Accounting } \\
\text { Application Skills }\end{array}$ & - & - & 10 & $05 \%$ & 190 & $95 \%$ \\
8ayroll Accounting \\
Application Skills \\
Computer Internet \\
Application Skills
\end{tabular}

Source: 2015 Field Survey

Extent of Competency in Computer Technology Skills of Business Education Graduating Students

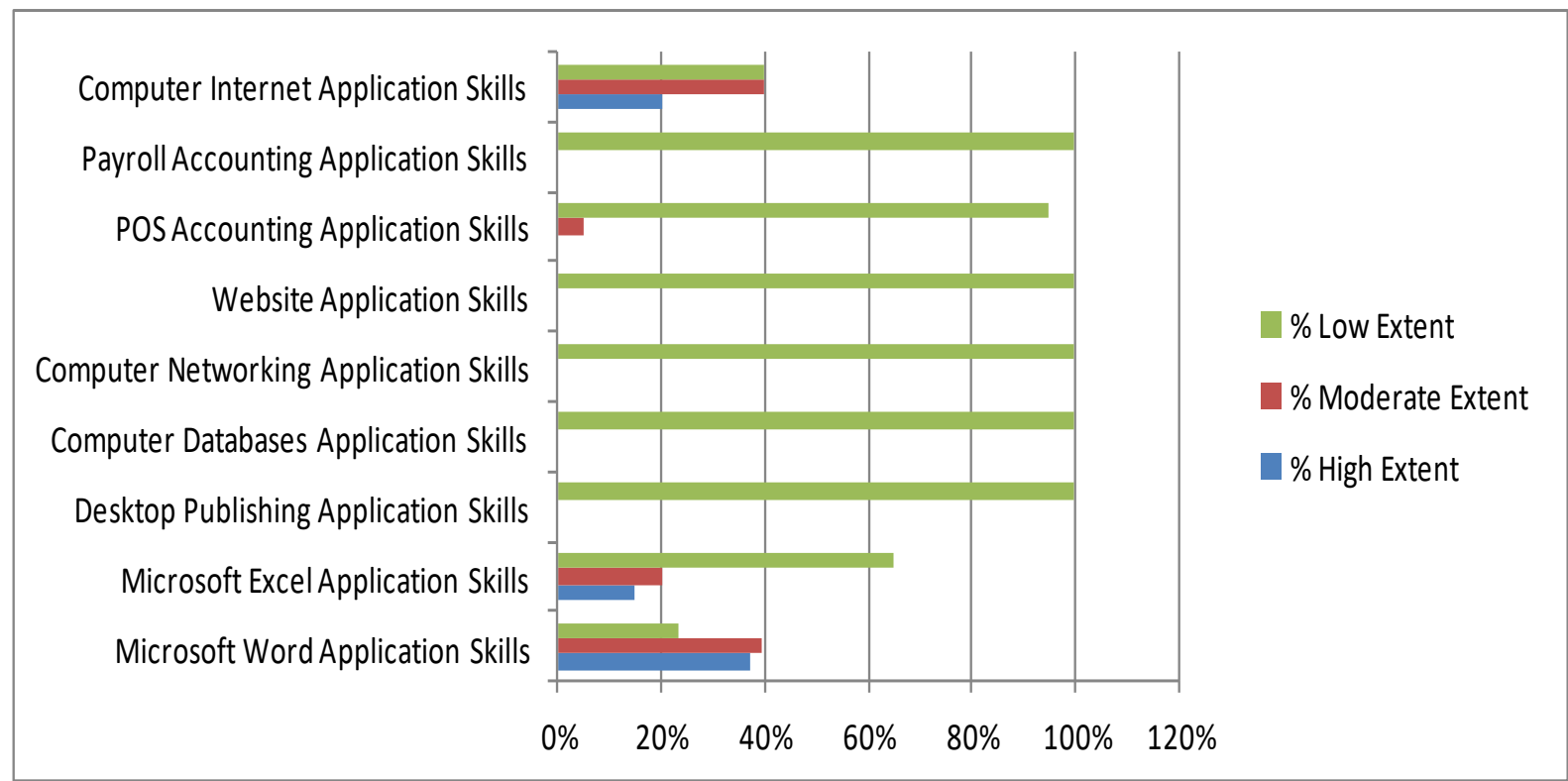


Table 2 and its bar chart shows that business education graduating students in Rivers State used for the study possess a low extent of competent level with $60 \%$ to $100 \%$ in the following computer technology skills expected of their employers: Microsoft Excel application skills, desktop publishing application skills, databases application skills, networking application skills, website application skills, POS accounting application skills, and payroll accounting application skills. The result also shows that the students rated their competency as moderate with $40 \%$ for the remaining skills expected of them by employers of labour.

\section{DISCUSSION OF FINDINGS}

The study reveals that the employers of business education graduates expect them to have a high competent level in computer application skills such as Microsoft Word, Microsoft Excel, Desktop Publishing, Databases, Computer Networking, Website Application, POS Application, Payroll Application and Computer Internet application skills. This is to enable them to utilize these various computer application areas to enhance their productivity in today's automated business world. These findings are in line with Chukwumezie and Ndinechi (2006) who posited that computer application areas for Business education students should cover areas like word processing and spreadsheet. The finding is also supported by Omeje (2008) who opined that adequate knowledge and skills on internet utilization is part of the expectation of the labour market from graduates of business education. Furthermore, the findings are inline with the assertion of Mehdi and Jun (2008) who noted that the labour market is in search of job seekers with higher competent skills related to computer databases, networking technologies, and website utilization among others. Ober (2011) also corroborated the findings when the author noted that most employment advertisements in this 21 st century emphasize the need for graduates to be proficient in Microsoft Office (mostly Word and Excel).

The study also reveals that business education graduating students possess a low competent level in almost all the computer application skills that are expected of them by the employers of labour. This rating is an indication that the students are inadequately prepared for the labour market which is meant to absorb most of them. Therefore, these graduating students will remain unfit for the labour market as a result of the gap in the extent of their competency in computer application skills needed in the labour market. The finding is in line with the discovery of Ezenwafor (2012) who discovered that business education students are inadequately exposed to the utilization of various computer application software resources. The finding is also supported by the discovery of Jegbefume, Utebor and Kifordu (2014) who discovered that business education students are barely proficient in spreadsheet processing application tasks required in the workplace. However, the finding is contrary to the discovery of Ndinechi and Ementa (2013) who discovered that students of business education rated their exposure to computer word processing skills through training very well.

\section{CONCLUSION}

In conclusion, the low extent competent level of business education graduates in computer application skills expected by the employers of labour significantly affects the students' employability. This is because the employers of labour prefer to employ those who have been trained to develop high competence in the required computer technology skills for employment 
than those who do not have the expected competency. Therefore, the findings of this study has an implication on the current computer application content in business education curriculum at the Nigeria Certificate in Education level. It also has an implication on the caliber of personnel employed to implement the computer application course content for business education at this level and the methodology adopted for training the students in computer application areas, since the computers are now provided through tertiary education fund intervention.

\section{RECOMMENDATIONS}

Based on the findings of this study and the conclusion drawn, the following recommendations are put forward:

i. Employers of business education graduates should collaborate with the National Commission for Colleges of Education to review the curriculum content for computer application areas in business education to cover skills in areas needed for their productivity.

ii. Existing business educators should be encouraged to go for continuous training in the areas of computer technology in the business world in order to empower themselves to guide the students appropriately towards developing relevant skills for the current labour market.

iii. Business education students who have already graduated and are lacking in the various computer technology skills highlighted in this study should endeavour to embark on personal development in order to develop such skills needed for employability.

iv. Potential business educators and instructors should be practically tested on computer application in a business performance test developed jointly by the management of institutions of higher learning and the immediate business environment practitioners.

\section{REFERENCES}

Achilike, A. N. (2007): The need for problem solving skills in the secretarial education curriculum: Business Education Journal: 6 (1): 197 - 206

Caliz, C. (2004): Designing new e-learning: retrieved from www.ssm.com/abstract-685822 on 22nd August, 2015.

Chukwumezie, F. U. \& Ndinechi, G. I. (2006): Word processing and electronic spreadsheets sub-skills required of secretaries for office career opportunities in private organizations: Business Education Journal: 5(2): 138 - 149

Ezenwafor, J. L. (2012): Adequacy of exposure to information and communication technology by graduating business education students of tertiary institutions in Anambra State: Business Education Journal: VIII (2): 45 - 60

Jegbefume, F. M.; Utebor, J. \& Kifordu, A. A. (2014): Challenges in the use of new learning technologies in business education programme: Nigerian Journal of Business

Education: 1(3): $306-312$ 
Mehdi, A. \& Jun, W. (2008): A pilot study of current trends in information and communication technology (ICT) education within the tertiary sector: Contemporary Management Research: 4 (4): 291 - 304

Ndinechi, G. I. \& Ementa, C. N. (2013): Business education students' rating of the teaching of word processing and desktop publishing skills in tertiary institutions in south east Nigeria: Nigerian Journal of Business Education: 1 (2): 75 - 82

Nwanewezi, M. C. \& Isifeh-Okpokwu, A. (2008): Factors militating against effective application of computer skills by confidential secretaries in business offices in Minna metropolis, Niger State: Business Education Journal: 6 (2): 59 - 65

Ober, S. (2011): Gregg college keyboarding and document processing (1 $1^{\text {th }}$ ed): New York: McGraw Hill

Oborah, J. O. \& Eze, M. E. (2013): Appraisal of the standard of performance in keyboarding by higher national diploma students in federal polytechnic Idah: Nigerian Journal of Business Education: 1 (2): 261 - 267

Omeje, T. S. (2008): Imperatives for reforming secretariat studies curriculum in Nigeria: Business Education Journal: 2 (1): 27 -37.

Onojetah, S. O. (2012): Challenges of implementing business education programme through information and communication technology (ICT): Association of Business Education of Nigeria Book of Readings: 2 (1): 156 - 162

Ramurez, L (2009): What is desktop publishing? Some history and answers: retrieved from www.selfpublishedbook.com on $23^{\text {rd }}$ August, 2015 